\title{
Does Crop-Livestock-Forest Systems Contribute to Soil Quality in Brazilian Savannas?
}

\author{
Leciana Menezes Souza Zago ${ }^{1}$, Werther Pereira Ramalho ${ }^{1}$, Samantha Caramori ${ }^{1}$ \\ ${ }^{1}$ Universidade Estadual de Goiás, Anápolis/GO, Brasil
}

\begin{abstract}
In this paper we discuss the impact on conversion degraded pasture areas into an integrated crop, livestock and forest system (ICLFS). We collected 30 soil samples at $0-0.1 \mathrm{~m}$ depth in five agroforestry systems, degraded pasture and native areas along Brazilian Cerrado biome. We analyzed the influence of chemical variables on microbial biomass carbon and enzyme activity using multivariate statistic analysis. The land use explained only the variation of microbial biomass carbon and seasonality explained the variation in glycine aminopeptidase activity. The sample controls differ from the other soil areas due to their greater biological activity (MBC). The enzymatic indicators showed that the biological activity is lower in degraded pasture. It was observed that the ICLFS system had a positive effect on the microbial activity (MBC and soil enzyme) when compared to pasture. This reinforces the importance of adopting more sustainable practices to improve soil quality.
\end{abstract}

Keywords: agroforestry systems, forest quality control, forest soil. 


\section{INTRODUCTION}

The transformations coming from anthropic action alter composition and amount of organic matter of the soil and directly affect its physical and chemical properties. These transformations imply perturbations and directly influence the microorganisms, microbial processes and nutrient cycling in the soil (Zago et al., 2018).

Crop, livestock and forest integration systems (ICLFS) were created with the aim of improving sustainability and ecosystem services (Lemaire et al., 2014). However, replacing specific production systems (e.g. grains, fibers, meat) with integrated agricultural production (ICLFS) generate impacts that can be positive or negative. The recovery of degraded pasture areas, increased food production and decrease in greenhouse gas emissions are benefits reported in the literature (Ozório \& Azevedo, 2014). On the other hand, intensification of land use, which is simultaneously used for livestock raising and timber production, can negatively affect the soil.

As this practice is being expanded in Brazil, research efforts are needed to evaluate soil quality and the impacts of ICLFS on an enzymatic activity in the soil, as well as to understand the behavior of the microbiota when degraded pasture areas are converted to agroforestry systems.

Several researches in ICLFS areas focus on the study and evaluation of physical and chemical properties (Stieven et al., 2014; Assis et al., 2015), but few scientific efforts have evaluated the biochemical activity of the soil in these agroecosystems (Sousa, 2010; Vinhal-Freitas et al., 2013). Within this context the following questions arise: 1) Does the conversion of areas of degraded pasture in ICLFS system improve the biochemical conditions of the soil? 2) Does land use influence biochemical activity and chemical properties in the soil? 3) Does seasonality influence biochemical activity and chemical properties? 4) Which chemical factors are most correlated with the enzymatic activity in different soil use conditions?

To answer these questions, the objective of the present study was to evaluate the chemical composition and activity of hydrolases involved in the carbon cycle ( $\beta$-glucosidase), phosphorus (acid phosphatase) and nitrogen (glycine aminopeptidase) in ICLFS areas. In addition, we sought to discuss the impact of conversion of degraded pasture areas to ICLFS, using as negative control degraded pasture soils and as positive control the native Cerrado soils.

\section{MATERIALS AND METHODS}

\subsection{Site description}

We selected five farms to evaluate if the implantation of crop-livestock-forest systems (ICLFS) changed the biochemical soil properties. The sampling areas are located in Cachoeira Dourada $\left(18^{\circ} 27.620^{\prime}\right.$ S $049^{\circ} 36.163$ W), Inaciolândia (18 $33^{\prime} 12.9^{\prime \prime}$ S 494 $47^{\prime} 53.7^{\prime \prime}$ W), Pontalina

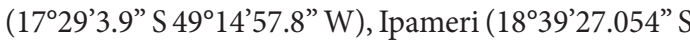
$\left.48^{\circ} 12^{\prime} 14.033^{\prime \prime} \mathrm{W}\right)$, situated in Goiás state, and Uberlândia $\left(19^{\circ} 09^{\prime} 38.00^{\prime \prime}\right.$ S $\left.48^{\circ} 10^{\prime} 19.63^{\prime \prime} \mathrm{W}\right)$, situated in Minas Gerais state. Besides the ICLFS, each property has conventional pasture (degraded) and native Cerrado in the same area.

According to Köppen's classification, the climate of the sampling regions is Aw, with the rainy season concentrate in spring-summer (October to April) and the dry season in autumn-winter (May to September). The annual temperature ranges from $4{ }^{\circ} \mathrm{C}$ to $40{ }^{\circ} \mathrm{C}$, and the annual rainfall varies between 1.229 and $1.750 \mathrm{~mm}$. In all sampling areas, the soils are classified as red latosols (EMBRAPA, 2013). The land use and soil tillage in crop-livestock-forest systems, degraded pasture and native Cerrado in the five study sites, are described in the Table 1.

\subsection{Soil sampling}

We collected the samples in the rainy (December 2016-February 2017) and drought seasons (July-September 2016). From each of the five farms, three sub samples of soil were randomly collected in crop-livestock-forest systems, degraded pasture and native Cerrado. Then we homogenized the samples to form one composite sample for each land use. The samples we collected along a grid in each plot $(5.0 \times 5.0 \mathrm{~m})$ to a depth of $0.10 \mathrm{~m}$, totaling 30 composite samples.

The soils were sieved $(<2 \mathrm{~mm})$ and packed in polyethylene bags at $4{ }^{\circ} \mathrm{C}$. We determined soil moisture content by drying $5 \mathrm{~g}$ of soil at $105{ }^{\circ} \mathrm{C}$ for $48 \mathrm{~h}$. Additionally, the soil chemical characteristics (Table 2) were determined according to the methodology of EMBRAPA (2011) 
Table 1. Land use and soil tillage in crop-livestock-forest systems (ICLFS), degraded pasture (DP) and native Cerrado (NC) in the five study sites.

\begin{tabular}{|c|c|c|}
\hline Site & Land use & Description of changes in the land use \\
\hline \multirow[t]{2}{*}{ S1 } & ICLFS & $\begin{array}{c}\text { The area is } 15 \text { ha long with three lines of Eucalyptus (Eucalyptus urograndis), } 14 \mathrm{~m} \text { between rows, } \\
\text { totalizing a set of triple lines (renques). The renques also have grass } 2 \mathrm{~m} \text { far from the lines of } \\
\text { Eucalyptus and } 3 \mathrm{~m} \text { between rows. }\end{array}$ \\
\hline & DP & The area composed of grass (Pennisetum clandestinum) is used as pasture for 15 years. \\
\hline \multirow[t]{2}{*}{ S2 } & ICLFS & $\begin{array}{l}\text { The area is } 70 \text { ha long with three lines of Eucalyptus (Eucalyptus urograndis), } 22 \mathrm{~m} \text { betweem rows, } \\
\text { resulting in a set of triple lines (renques). The renques have grass, } 2 \mathrm{~m} \text { far from plants on the line } \\
\text { and } 3 \mathrm{~m} \text { between lines. }\end{array}$ \\
\hline & DP & The area composed of grass is used as pasture for 12 years. \\
\hline \multirow[t]{2}{*}{ S3 } & ICLFS & $\begin{array}{c}\text { The area is } 15 \text { ha long, has four lines of mahogany, being } 22 \mathrm{~m} \text { between rows in the set of triple } \\
\text { lines (renques). The renques have grass } 5 \mathrm{~m} \text { distance between plants on the line and } 3 \mathrm{~m} \text { between } \\
\text { rows. }\end{array}$ \\
\hline & DP & The area composed of grass is used as pasture for 10 years. \\
\hline \multirow[t]{2}{*}{ S4 } & ICLFS & $\begin{array}{l}\text { The area has } 70 \text { ha with four lines of Eucalyptus, being } 16 \mathrm{~m} \text { between rows (renques), composed of } \\
\text { grass } 3 \mathrm{~m} \text { distance between plants on the line and } 2.5 \mathrm{~m} \text { between rows. }\end{array}$ \\
\hline & DP & The area composed of grass (Brachiaria sp.) is used as pasture for 13 years. \\
\hline \multirow[t]{2}{*}{ S5 } & ICLFS & $\begin{array}{l}\text { The area has } 70 \text { ha with four lines of Eucalyptus, being } 16 \mathrm{~m} \text { between rows in the set of triple lines } \\
\text { (renques), composed of grass } 3 \mathrm{~m} \text { distance between plants on the line and } 2.5 \mathrm{~m} \text { between rows. }\end{array}$ \\
\hline & DP & The area composed of grass (Brachiaria brizantha) is used as pasture for 8 years. It has a total area of 5.7 ha. \\
\hline $\begin{array}{l}\text { All the } \\
\text { areas }\end{array}$ & NC & area. \\
\hline
\end{tabular}

S1: Cachoeira Dourada; S2: Inaciolândia; S3: Pontalina; S4: Ipameri; S5: Uberlândia.

\subsection{Soil biochemical characteristics}

We evaluated three soil enzymes ( $\beta$-glucosidase, acid phosphatase and glycine aminopeptidase) in the present study. We assayed the activities of $\beta$-glucosidase (EC 3.2.1.21) and acid phosphatase (EC 3.1.3.2), as described by Baldrian et al. (2005). For determination of the glycine aminopeptidase activity (EC 3.4.11), it was used the method of Allison \& Vitousek (2005) with some modifications. Next, $0.1 \mathrm{~g}$ dry mass soil was incubated at $37^{\circ} \mathrm{C}$ for $60 \mathrm{~min}$, using $900 \mu \mathrm{L} p$-nitroanilide prepared in sodium acetate buffer at $\mathrm{pH} 5.0$ as described in the original method. To build the controls, sodium acetate buffer replaced the substrate volume. We expressed the results as $\mu \mathrm{g}$ of released $p$-nitrophenol or $p$-nitroaniline $\mathrm{g}^{-1}$ soil h$^{-1}$ at 400 or $405 \mathrm{~nm}$.

For determination of the Microbial Biomass Carbon (MBC) we evaluated samples by irradiation-incubation method (Ferreira et al., 1999). The results were expressed in microgram of carbon per gram of soil $\left(\mu \mathrm{g} \mathrm{C}^{-1}\right)$.

\subsection{Data analysis}

The variations in each enzyme activity among different land uses and their interactions were evaluated through permutational multivariate analyzes of variance (PERMANOVA). Linear Discriminant Analysis (LDA) was used to group the biochemical ( $\mathrm{MBC}$ and enzymes) and chemical variables $(\mathrm{P}, \mathrm{K}, \mathrm{Ca} / \mathrm{Mg}, \mathrm{Mg} / \mathrm{CEC}, \mathrm{K} / \mathrm{CEC}, \mathrm{Hal}, \mathrm{NT}$ ) according to the land use (Cerrado, ICLFS and pasture). The chemical variables with the lowest inflation value $(\mathrm{VIF}<3)$ were selected by the multicollinearity test (Zainodin et al., 2011).

The influence of the chemical variables on MBC activity and enzyme activity was evaluated by multiple step regression with reverse selection. For each biochemical variable, we constructed regression-filled models with the seven chemical predictors. To meet the assumptions of the tests, the data were used in logarithmic scale (log and $\log +1$, respectively). Analyses were performed in R software (R Core Team, 2017) using the lda function (package MASS) and Im (package Vegan), respectively.

\section{RESULTS AND DISCUSSION}

Analysis of soil enzyme activities and MBC by PERMANOVA are presented in Figure 1 and Table 3. It seems that an effect of the land use on the enzymatic activity is observed in Figure 1A-C. But when enzymatic activity was analyzed simultaneously in the three land use soils (Table 3), we noted that the variations are not statistically significant $(\mathrm{p}<0.05)$ among soil use samples. 


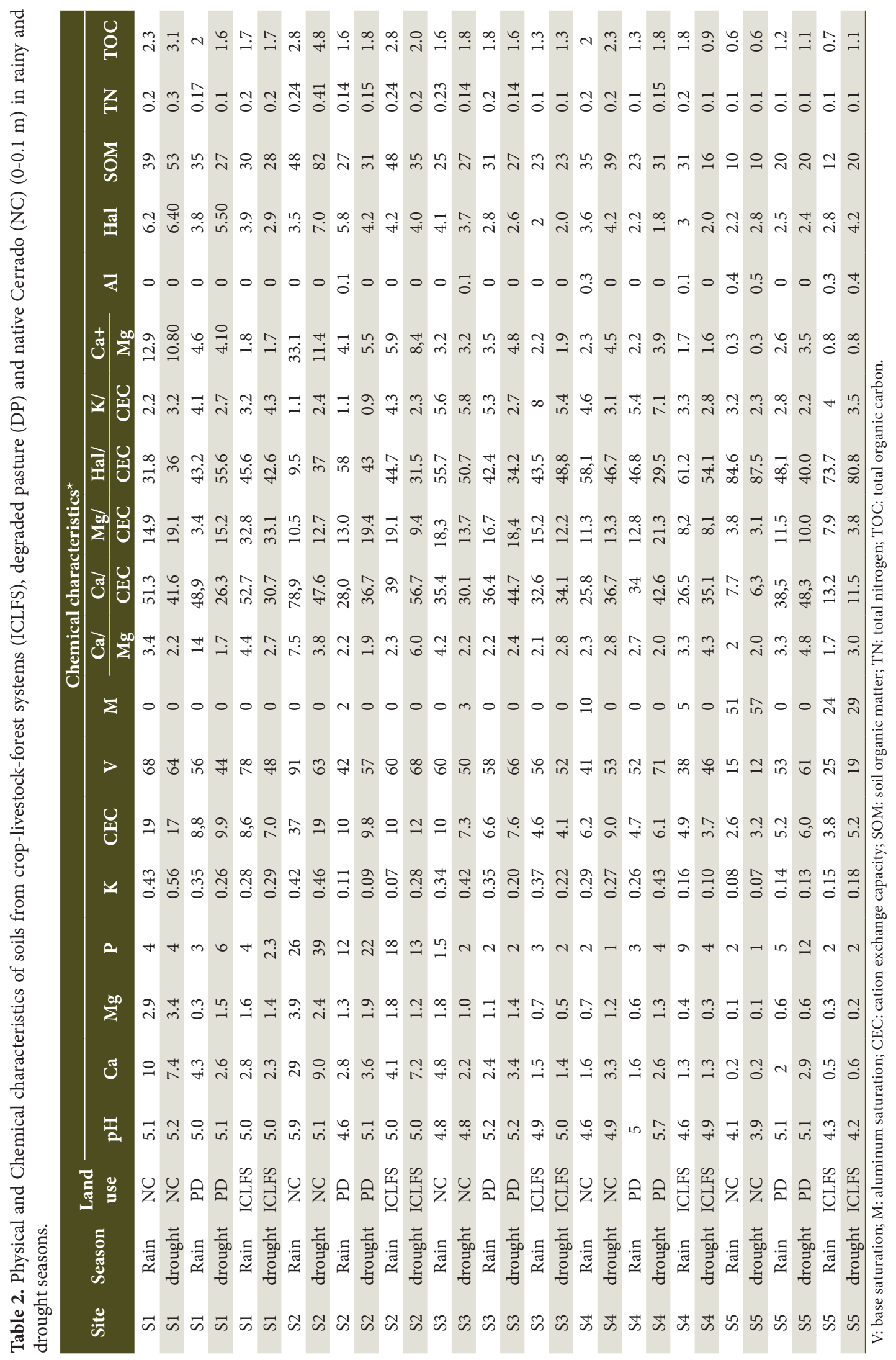



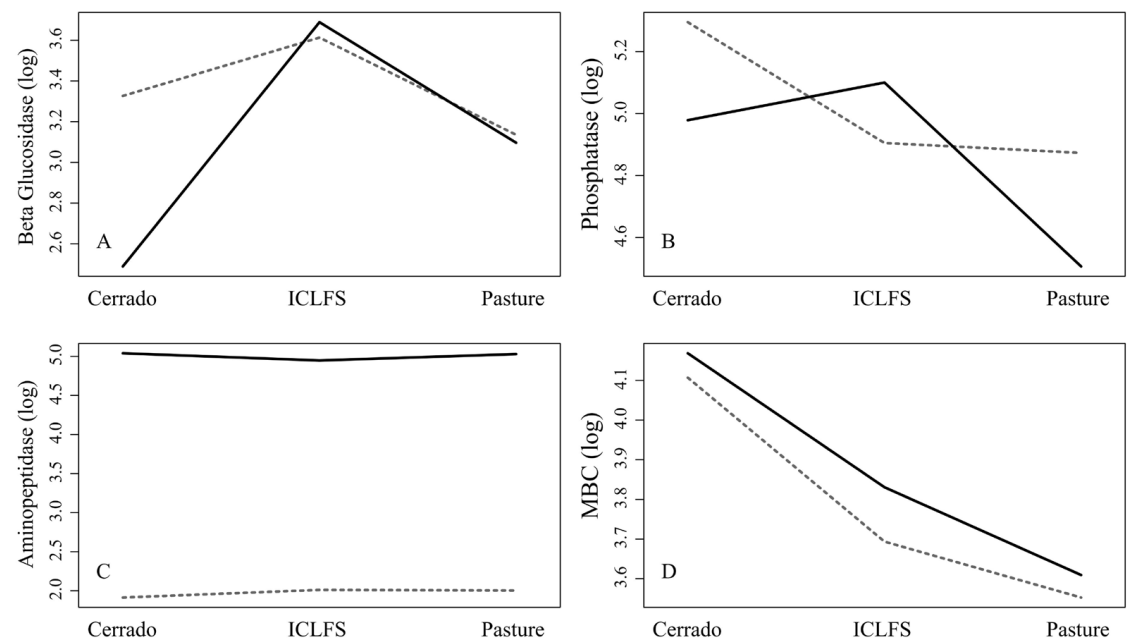

Figure 1. Variation in the activity of $\beta$-glucosidase (A), acid phosphatase (B), glycine aminopeptidase (C) and MBC (D) between rainy periods (dark lines) and dry (dotted lines) at different land use. All enzyme activity values were $\log$ transformed $(\log )$ prior to analysis.

Table 3. Influence of predictive variables of soil use, seasonal period and their interactions on MBC and aminopeptidase, phosphatase and $\beta$-glucosidase activities, using the permutational analysis of variance.

\begin{tabular}{|c|c|c|c|c|c|}
\hline $\begin{array}{l}\text { Predictor } \\
\text { variables }\end{array}$ & Df & Mean Sq & F model & $\mathbf{R}^{2}$ & $\operatorname{Pr}(>\mathbf{F})$ \\
\hline \multicolumn{6}{|c|}{ Microbial Biomass Carbon } \\
\hline Land use & 2 & 0.81 & 5.08 & 0.29 & 0.02 \\
\hline Season & 1 & 0.05 & 0.34 & 0.01 & 0.56 \\
\hline Land use: Season & 2 & 0.01 & 0.03 & 0.00 & 0.97 \\
\hline Residuals & 24 & 0.16 & - & 0.69 & - \\
\hline \multicolumn{6}{|c|}{ Aminopeptidase } \\
\hline Land use & 2 & 0.01 & 0.04 & 0.00 & 0.93 \\
\hline Season & 1 & 68.81 & 545.17 & 0.96 & $<0.01$ \\
\hline Land use: Season & 2 & 0.02 & 0.18 & 0.00 & 0.85 \\
\hline Residuals & 24 & 0.13 & & 0.04 & \\
\hline \multicolumn{6}{|c|}{ Phosphatase } \\
\hline Land use & 2 & 0.53 & 0.74 & 0.06 & 0.61 \\
\hline Season & 1 & 0.20 & 0.28 & 0.01 & 0.75 \\
\hline Land use: Season & 2 & 0.24 & 0.34 & 0.03 & 0.86 \\
\hline Residuals & 24 & 0.71 & & 0.91 & \\
\hline \multicolumn{6}{|c|}{ Beta glucosidase } \\
\hline Land use & 2 & 1.47 & 2.21 & 0.14 & 0.13 \\
\hline Season & 1 & 0.53 & 0.81 & 0.03 & 0.36 \\
\hline Land use: Season & 2 & 0.62 & 0.93 & 0.06 & 0.40 \\
\hline Residuals & 24 & 0.66 & & 0.77 & \\
\hline
\end{tabular}

$\mathrm{Df}=$ degree of freedom; Mean Sq = mean square; $\mathrm{F}$ model $=\mathrm{F}$ value; $\mathrm{R}^{2}$ = index of correlation; $\operatorname{Pr}(>\mathrm{F})=\mathrm{P}$ value indicating significance.

However, when comparing $\beta$-glucosidase, acid phosphatase and $\mathrm{MBC}$ activity between agroforestry and pasture systems, the values were more significant in ICLFS (Figure 1A, B, D).

Intensification in land use generates stress in the microbiota, increases metabolic and enzymatic activity in the soil and shifts the rates of organic matter decomposition (Trasar-Cepeda et al., 2008). Otherwise, if the microbiota is under a new environmental condition (agroecosystem), the management effects or natural conditions can sometimes be subtle and slow and not be evident until the microbiota responds to the additional stress (Reed et al., 2009). 
The results of the permutacional multivariate analysis of variance (PERMANOVA) showed that the predictive variable "land use" was important to explain the variation in $\mathrm{MBC}$ (F model $\left.=5.08, \mathrm{R}^{2}=0.29, \mathrm{DF}=2, \mathrm{p}=0.02\right)$. The values were higher in areas of Cerrado in relation to ICLFS and pasture (Figure 1D).

The soil microbial biomass (SMB) is responsible for biological and biochemical processes in the soil and can be altered by the conditions of the environment in which they are inserted (Martins et al., 2018). In the Cerrado, the high amount of plant species and presence of plants with a high developed root system than the aerial part allow greater abundance of organic residues, enzymatic substrates and nutrients, as well as better aeration of the soil (Myers et al., 2000).

Deep root system provides greater exudation of organic compounds that are used as source of carbon and energy by the SMB, favoring the growth of microorganisms (Souza et al., 2006). These no-tillage environments provide better survival conditions and metabolic activity of soil microorganisms, which explain our results in Figure 1 D (Schmidt et al., 2018).

The results show that the interaction between period and land use was not important to explain the variation in enzyme activity (Figure 1, Table 3 ). The enzymes $\beta$-glucosidase and acid phosphatase did not have their activities influenced by the seasonal period. However, glycine aminopeptidase activity presented statistically significant variation between the periods of the year (rain and dry), being higher during the rain in relation to the dry period ( $\mathrm{F}$ model $=545.17, \mathrm{R}^{2}=0.96, \mathrm{DF}=1 . \mathrm{p}<0.01 ;$ Figure 1).

Increases in glycine aminopeptidase activity indicated that soil moisture content is a factor that alters the extracellular activity of aminopeptidases (Lemaire et al., 2014; Zago et al., 2017). One of the explanations would be that fluctuations in precipitation and temperature throughout the year modify the survival conditions of mycorrhizal bacteria and fungi, which tend to present higher growth rates in moist soils. Moreover, the increased availability of nitrogen residues coming from soil deposition in the dry season also directly interferes in the quantitative of enzymes, diffusion of the substrates and catalytic activity in the soil (Borowik \& Wyszkowska, 2016, Burns et al., 2013).

In general, acid phosphatase presented higher activity in all land use groups, and in the dry period it was higher in the Cerrado areas. Some research studies have found similar results and corroborate our findings (Lemaire et al., 2014; Zago et al., 2018). The highest levels of acid phosphatase activity in Cerrado compared to other areas (DP and ICLFS) may be associated with the amount of organic phosphate (P org), relatively lower in the natural areas evaluated in the present study (Table 1).

Phosphatases are synthesized and exported to the extracellular medium when the concentrations of soluble phosphorus reach limiting levels for plant growth and soil microorganisms. Thus, the synthesis of phosphatases is controlled by the concentration of inorganic phosphate and regulated by mechanisms of self-repression by inorganic phosphate $(\mathrm{Pi})$ that came from organic phosphate (Nahas, 2015).

The synthesis of phosphatase depends not only on the availability of phosphate in the soil (available $\mathrm{P}$ org and limitation of Pi) (Nahas, 2015), but also by the plant and microorganisms demand for $\mathrm{Pi}$, water availability, carbon and nitrogen (Marklein \& Houlton, 2012; Allison \& Vitousek, 2005). In addition, depending on the anthropic activity and the established soil culture, phosphatase activity may also be altered (Zago et al., 2018). In the present study, TN, TOC and SOM levels were on average higher in the areas of native Cerrado $(0.21,2.19$, and 36.8 , respectively) than in the anthropic areas $(013,1.58,27.2$ for DP and $0.15,1.53,26.6$ for ICLFS), corroborating with the aforementioned studies. Thus, the set of analyzed variables (chemical and biochemical) seems to have exerted a great influence on the enzymatic action of phosphatase (Neal et al., 2017).

The LDA provided a correct classification of $57 \%$ of the groups for total soil biochemical activity, in which $70 \%$ were correct for Cerrado, $40 \%$ for ICLFS and $60 \%$ for pasture (Figure 2). In Figure 2A it is possible to observe that the enzymatic activities increased in the ICLFS and pasture on the left of the biplot and in the Cerrado occurred on the right of the biplot, but they share few characteristics. Therefore, the results of the model analysis revealed differences and similarities between the evaluated environments (native Cerrado, pasture and ICLFS) and showed that the biochemical attributes, verified by hydrolase activities, were indicators to assess land use. 

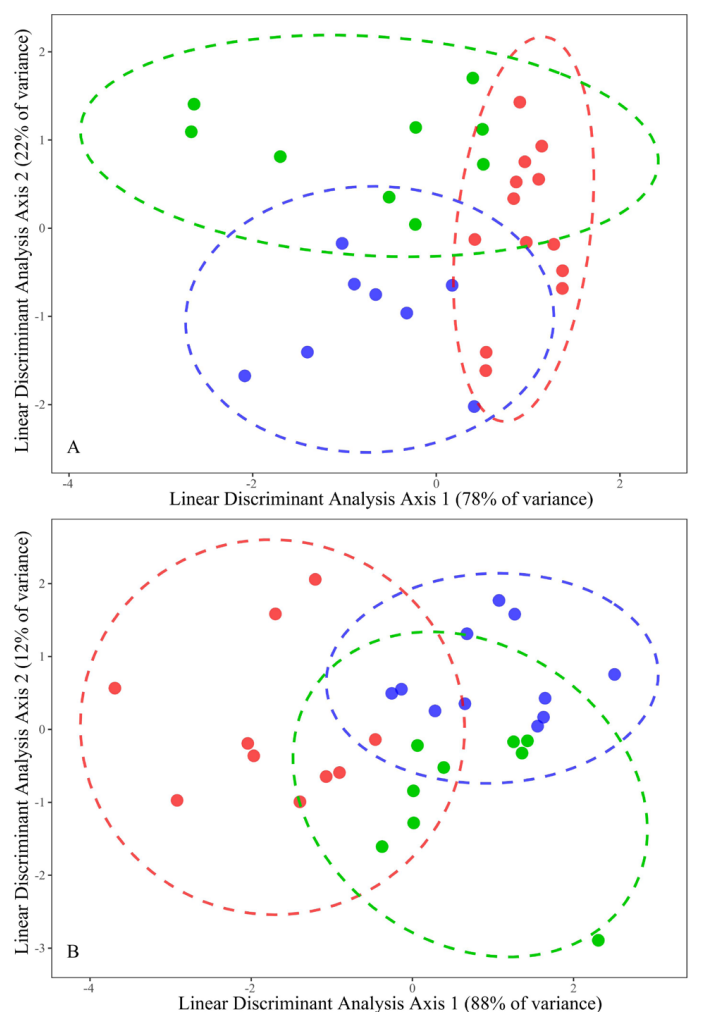

Figure 2. Linear discriminant analysis (LDA) of responses of $\mathrm{MBC}$ and three soil enzyme activities (A) and chemical variables (B) in crop-livestock-forest systems, pasture and native Cerrado (Red).

The first axis explained $78 \%$ of the total variance in biochemical data and showed that the Cerrado differs from the other areas due mainly to the greater biological activity (MBC). The results of the discriminant analysis (Figure 2) show that all Cerrado areas are nearby and grouped together. In this way it can be inferred that these environments (Cerrado) present a distinct dynamics of microbial functioning and metabolism, which reflects the absence of management, in relation to the other studied areas (ICLFS and pasture). These findings indicate that, under natural conditions, there is a greater environmental balance. This promotes better conditions for the metabolic activity of the microbiota and enzyme stabilization in microenvironments, conferring greater nutrient cycling and better soil quality when compared to agroforestry system (Stieven et al., 2014).

The second axis explained $22 \%$ of the variance in biochemical data and separated the groups vertically, indicating higher $\beta$-glucosidase activity in ICLFS, acid phosphatase in Cerrado and aminopeptidase in pasture (Figure 2). Many studies indicate that soil use promotes a decrease on enzyme activity (Lemaire et al., 2014; Zago et al., 2016), but this research shows that $\beta$-glucosidase and glycine aminopeptidase operated higher in agricultural systems. In this case, the enzyme activity varied depending on the land use distinctly for each enzyme, being smaller or larger than in native Cerrado soils.

We can note that the average value of SOM, TOC and TN are considerably lower in ICLFS (38\%, 37\% and $43 \%$, respectively) than in the natural environment (Cerrado), while the variation in metabolic activity (MBC) among such areas is only $0.95 \%$. According to Trasar-Cepeda et al. (2008), such results could be indicative of stress on soil microbiota, which in turn responded with increased enzyme activity. Another fact is that the metabolic activity (MBC) in ICLFS is very similar to the Cerrado, because the contents of SOM, TOC and TN are not high. Within this context, we suggest that the fall of leaves and stems from the arboreal component allows greater deposition of organic compounds rich in cellulose, which is used as a substrate for the action of $\beta$-glucosidase.

Regarding the enrichment of the glycine aminopeptidase activity in pasture soils, we observed that the TOC and SOM levels are higher in pasture (1.58 and 27.2, respectively) and slightly lower in ICLFS (1.53 and 26.6, respectively). The increase on the enzyme activity may represent an ecological mechanism to conserve the metabolic activity in the soil. As they are exported to the soil matrix, the enzyme molecules associate physically or chemically on soil particles, expanding the aminopeptidase activity in cultivated environments (Trasar-Cepeda et al., 2008).

For the chemical composition, the discriminant model correctly predicted the classification of $77 \%$ of the groups of soil use, being $80 \%$ of success for the Cerrado, $70 \%$ for ICLFS and $80 \%$ for pasture. We can observe that the level of correctness for the chemical attributes was higher than on the LDA for biochemical activity, suggesting that the model (LDA) is useful to explain variations in soil attributes.

Figure $2 \mathrm{~B}$ shows that, unlike enzymatic activity, the chemical attributes of the Cerrado are partially distributed on the left of the biplot and the anthropic areas (ICLFS and pasture) are on the right of the biplot. 

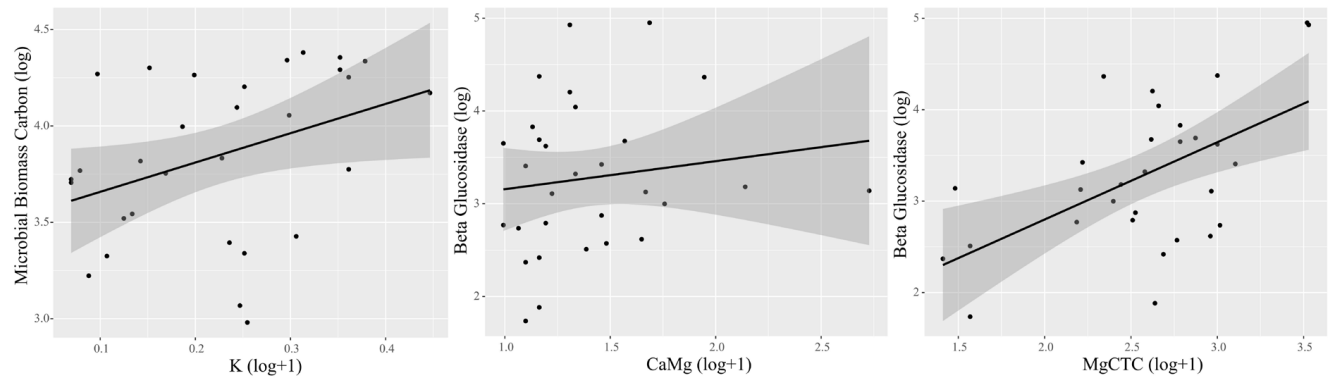

Figure 3. Variations of $\mathrm{MBC}$ and $\beta$-glucosidase activity as a function of the chemical variables selected by the stepwise multiple regression model by backward selection.

This fact occurred because the areas of ICLFS are originated from the transformation of pasture areas in agroforestry environments.

The mean values indicated that are major levels of $\mathrm{K}^{+}, \mathrm{H}^{+} \mathrm{Al}$ and NT in Cerrado soils. On the other hand, the $\mathrm{Ca} / \mathrm{Mg}$ and $\mathrm{K} / \mathrm{CTC}$ ratios were higher in ICLFS and the ratio $\mathrm{Mg} / \mathrm{CTC}$ and the level of $\mathrm{P}$ was more abundant in pasture soils. Some efforts conducted in agroforestry systems show significant variations between ICLFS and native forest (Assis et al., 2015).

High acidity is a characteristic of Cerrado soils that tend to present high levels of aluminum $(>1.0 \mathrm{cmolc})$ and offer higher exchangeable acidity or potential acidity $\left(\mathrm{H}^{+} \mathrm{Al}\right.$ ) (Iwata et al., 2012). However, several endemic Cerrado species are adapted to this condition and contribute to the physiognomic and structural profile of the vegetation (Klink \& Machado, 2005). The abundance of $\mathrm{K}^{+}$in the Cerrado soils can be associated with high decomposition performed by the soil biota or even by their mineralogical composition. Finally, the greater abundance of litter in Cerrado soils can explain the correlation between TN and SOM in these samples.

Agricultural environments presented more expressive $\mathrm{Ca} / \mathrm{Mg}$ and $\mathrm{K} / \mathrm{CTC}$ values in ICLFS and the ratio $\mathrm{Mg} / \mathrm{CTC}$ pasture areas, showing the alterations of chemical fertilization on the soil chemical properties. This can interfere on nutrient cycling via disturbing in enzyme activity exportation. In agricultural areas, the highest values of CEC are indicative that higher amounts of nutrients are mobilized in the soil and will become available to the plants, improving their development.
Multiple stepwise regression models provided evidence that there are positive relationships between biochemical and chemical variables (Figure 3). Variations in $\mathrm{MBC}$ were positively associated $\left(\mathrm{R}^{2}=0.14 ; \mathrm{F}=4.71 ; \mathrm{p}=0.04\right)$ with the levels of $\mathrm{K}^{+}($Estimate $=1.72 ; \mathrm{t}$ value $=2.17 ; \mathrm{p}=0.04)$. These data are in agreement with those obtained by the LDA, which showed that the $\mathrm{K}^{+}$content is higher in Cerrado areas (Table 3).

Variations on $\beta$-glucosidase activity were positively associated $\left(\mathrm{R}^{2}=0.41 ; \mathrm{F}=9.20 ; \mathrm{p}<0.01\right)$ to $\mathrm{Mg} / \mathrm{CTC}$ $($ Estimate $=0.97 ; \mathrm{t}$ value $=4.18 ; \mathrm{p}<0.01)$ and $\mathrm{Ca} / \mathrm{Mg}$ ratio $($ Estimate $=0.66 ;$ t value $=2.03 ; \mathrm{p}=0.05)($ Figure 3$)$. Both values were higher in agricultural areas (Table 2). These findings indicate that the activity of $\beta$-glucosidase is positively influenced by the $\mathrm{Ca}^{2+}$ and $\mathrm{Mg}^{2+}$ contents, as well as the ability of the soil to bind to these and other cations present in the soil solution (CEC), which in turn is dependent on SOM (Mukherjee \& Zimmerman, 2013).

Thus, the results reinforce the evidence that soil chemical conditions may interfere with its biochemical activity (Lemaire et al., 2014). In addition, the regression analysis indicated that the activities of the acid phosphatase and aminopeptidase were not explained by the analyzed chemical variables, showing that those chemical parameters do not determine the activity of such enzymes.

\section{CONCLUSIONS}

Soils in pasture and ICFLS have distinct biochemical and chemical composition, but some chemical and biochemical characteristics are shared in the three environments (native Cerrado, ICLFS and pasture). 
In general, seasonality does not exert effects on biochemical/chemical components of the soil.

The ICLFS system had a positive effect on MBC and soil enzymes, when compared to pasture, reinforcing the importance of adopting more sustainable practices for soil health. Finally, LDA and discriminant analysis evidenced the positive relationships between biochemical and chemical variables in the soils. We recommend the model analysis (LDA) to identify differences from land use, and to identify possible soil quality indicators in agroforestry systems.

\section{ACKNOWLEDGEMENTS}

To Universidade Estadual de Goiás, Agreement UEG/CAPES - PROAP, and PROBIP/UEG.

\section{SUBMISSION STATUS}

Received: 25 jul., 2018

Accepted: 9 apr., 2019

\section{CORRESPONDENCE TO}

\section{Samantha Caramori}

CCET, Universidade Estadual de Goiás - UEG, Rodovia BR 153, 3105, CEP 75132-903, Anápolis, GO, Brasil.

e-mail: sscaramori@gmail.com

\section{FINANCIAL SUPPORT}

UEG/CAPES (Grant/Award Number: 817164/2015 - PROAP).

\section{REFERENCES}

Allison SD, Vitousek PM. Responses of extracellular enzymes to simple and complex nutrient inputs. Soil Biology \& Biochemistry 2005; 37(5): 937-944. http:// dx.doi.org/10.1016/j.soilbio.2004.09.014.

Assis PCR, Stone LF, Medeiros JC, Madari BE, Oliveira JM, Wruck FJ. Physical attributes of soil in integrated croplivestock-forest systems. Brazilian Journal of Agricultural Environmental Engineeering 2015; 19(4): 309-316.

Baldrian P, Valáskova V, Merhautová V, Gabriel J. Degradation of lignocellulose by Pleurotus ostreatus in the presence of copper, manganese lead and zinc. Research in Microbiology 2005; 156(5-6): 670-676. http://dx.doi. org/10.1016/j.resmic.2005.03.007. PMid:15921894.

Borowik A, Wyszkowska J. Soil moisture as a factor affecting the microbiological and biochemical activity of soil. Plant, Soil and Environment 2016; 62(6): 250-255. http://dx.doi.org/10.17221/158/2016-PSE.

Burns RG, DeForest JL, Marxsen J, Sinsabaugh RL, Stromberger ME, Wallenstein MD et al. Soil enzymes in changing environment: current knowledge and future directions. Soil Biology \& Biochemistry 2013; 58: 216-234. http://dx.doi.org/10.1016/j.soilbio.2012.11.009.

Empresa Brasileira de Pesquisa Agropecuária - Embrapa. Manual de método de análise de solo. 2. ed. Brasília: Embrapa Solos; 2011.

Empresa Brasileira de Pesquisa Agropecuária - Embrapa. Sistema brasileiro de classificação de solos. 3. ed. Brasília: Embrapa Solos; 2013.

Ferreira AS, Camargo FAO, Vidor C. Utilização de micro-ondas na avaliação da biomassa microbiana do solo. Brazilian Journal of Soil Science 1999; 23: 991-996.

Iwata BF, Leite LFC, Araújo ASF, Nunes LAPL, Gehring C, Campos LP. Agroforestry systems and its effects on chemical attributes of an Ultisol in the 'Cerrado' of Piaui state, Brazil. Revista Brasileira de Engenharia Agrícola e Ambiental 2012; 16(7): 730-738. http://dx.doi.org/10.1590/ S1415-43662012000700005.

Klink CA, Machado RB. Conservation of the Brazilian Cerrado. Conservation Biology 2005; 19(3): 707-713. http:// dx.doi.org/10.1111/j.1523-1739.2005.00702.x.

Lemaire G, Franzluebbers A, Carvalho PCF, Dedieu B. Integrated crop-livestock systems: Strategies to achieve synergy between agricultural production and environmental quality. Agriculture, Ecosystems \& Environment 2014; 190(1): 4-8. http://dx.doi.org/10.1016/j.agee.2013.08.009.

Marklein AR, Houlton BZ. Nitrogen inputs accelerate phosphorus cycling rates across a wide variety of terrestrial ecosystems. The New Phytologist 2012; 193(3): 696-704. http://dx.doi.org/10.1111/j.1469-8137.2011.03967.x. PMid:22122515.

Martins JR, Fernandes LA, Oliveira ALG, Sampaio RA, Frazão LA. Soil microbial attributes under agroforestry systems in the cerrado of Minas Gerais. Floresta e Ambiente 2018; 25(1): e20160476. http://dx.doi.org/10.1590/21798087.047616.

Mukherjee A, Zimmerman AR. Organic carbon and nutrient release from a range of laboratory-produced biochars and biochar-soil mixtures. Geoderma 2013; 193-194: 122130. http://dx.doi.org/10.1016/j.geoderma.2012.10.002.

Myers N, Mittermeier RA, Mittermeier CG, Fonseca GA, Kent J. Biodiversity hotspots for conservation priorities. Nature 2000; 403(6772): 853-858. http://dx.doi. org/10.1038/35002501. PMid:10706275. 
Nahas E. Control of acid phosphatases expression from aspergillus niger by soil characteristics. Brazilian Archives of Biology and Technology 2015; 58(5): 658-666. http:// dx.doi.org/10.1590/S1516-89132015050485.

Neal AL, Rossmann M, Brearley C, Akkari E, Guyomar $\mathrm{C}$, Clark IM et al. Land-use influences phosphatase gene microdiversity in soils. Environmental Microbiology 2017; 19(7): 2740-2753. http://dx.doi.org/10.1111/14622920.13778. PMid:28447381.

Ozório RML, Azevedo DB. Experts' perceptions to climate changes: agriculture-stock-raising-forest integration as sustainable alternative for the production of food, fibers and energy in agribusiness. Revista em Agronegócio e Meio Ambiente 2014; 7(2): 257-278.

R Core Team. R: A language and environment for statistical computing [online]. Vienna: R Foundatiton for Statistical Computing; 2017 [cited 2018 Apr 10]. Available from: https://www.R-project.org/

Reed HE, Blair JM, Wall DH, Seastedt TR. Impacts of management legacies on litter decomposition in response to reduced precipitation in a tallgrass prairie. Applied Soil Ecology 2009; 42(2): 79-85. http://dx.doi.org/10.1016/j. apsoil.2009.01.009.

Schmidt R, Gravuer K, Bossange AV, Mitchell J, Scow K. Long-term use of cover crops and no-till shift soil microbial community life strategies in agricultural soil. PLoS One 2018; 13(2): e0192953. http://dx.doi.org/10.1371/journal. pone.0192953. PMid:29447262.

Sousa ED. Soil microbial biomass in a no-tillage integrated crop-livestock system under different grazing intensities. Revista Brasileira de Ciência do Solo 2010; 34(1): 79-88.

Souza ED, Carneiro MAC, Paulino HB, Silva CA, Buzetti S. Fraçoes do carbon orgânico, biomassa e atividade microbiana em um Latossolo Vermelho sob Cerrado submetido a diferentes sistemas de manejos e usos do solo. Acta Scientiarum. Agronomy 2006; 28(3): 323-329. http://dx.doi.org/10.4025/actasciagron.v28i3.940.

Stieven AC, Oliveira DA, Santos JO, Wruck FJ, Campos DTA. Impacts of integrated crop-livestock-forest on microbiological indicators of soil. Agrária 2014; 9(1): 53-58. http://dx.doi.org/10.5039/agraria.v9i1a3525.

Trasar-Cepeda C, Leirós MC, Gil-Sotres F. Hydrolytic enzyme activities in agricultural and forest soils. Some implications for their use as indicators of soil quality. Soil Biology \& Biochemistry 2008; 40(9): 2146-2155. http:// dx.doi.org/10.1016/j.soilbio.2008.03.015.

Vinhal-Freitas IC, Ferreira AS, Corrêa GF, Wendling B. Land use impacto $\mathrm{n}$ microbial and biochemical indicators in agroecossystems of the Brasilian Cerrado. Vadose Zone Journal 2013; 12(1): 2-8. http://dx.doi.org/10.2136/vzj2012.0027.

Zago LMS, Moreira AKO, Silva-Neto CM, Nabout JC, Ferreira ME, Caramori SS. Biochemical activity in Brazilian Cerrado soils is differentially affected by perennial and annual crops. Australian Journal of Crop Science 2018; 12(2): 235-242. http://dx.doi.org/10.21475/ajcs.18.12.02.pne716.

Zago LMS, Oliveira RN, Bombonatto AKG, Moreira LMO, Melo ENP, Caramori SS. Extracellular enzymes from Cerrado soils as quality bioindicators in agricultural areas in Goiás, Brazil. Fronteiras. Journal of Social and Technological Environmental Science 2016; 5(1): 104-127.

Zago LMS, Sousa VR, Caramori SS. Biochemical indicators as parameters of changes in the fertility of Brasilian Cerrado soils. International Journal of Current Research 2017; 9(5): 50979-50985.

Zainodin HJ, Noraini A, Yap SJ. An Alternative Multicollinearity Approach in Solving Multiple Regression Problem. Trends in Applied Sciences Research 2011; 6(11): 1241-1255. http://dx.doi.org/10.3923/tasr.2011.1241.1255. 